\title{
Pharmacological Properties and Physiological Function of a P2X-Like Current in Single Proximal Tubule Cells Isolated from Frog Kidney
}

\author{
John P. Davies • Louise Robson
}

Received: 22 July 2010/Accepted: 22 September 2010/Published online: 23 October 2010

(C) The Author(s) 2010. This article is published with open access at Springerlink.com

\begin{abstract}
Although previous studies have provided evidence for the expression of $\mathrm{P} 2 \mathrm{X}$ receptors in renal proximal tubule, only one cell line study has provided functional evidence. The current study investigated the pharmacological properties and physiological role of native P2X-like currents in single frog proximal tubule cells using the whole-cell patch-clamp technique. Extracellular ATP activated a cation conductance $\left(\mathrm{P} 2 \mathrm{X}_{\mathrm{f}}\right)$ that was also $\mathrm{Ca}^{2+}$ permeable. The agonist sequence for activation was $\mathrm{ATP}=\alpha \beta$-MeATP $>$ BzATP $=2$-MeSATP, and P2X was inhibited by suramin, PPADS and TNP-ATP. Activation of $\mathrm{P} 2 \mathrm{X}_{\mathrm{f}}$ attenuated the rundown of a quinidine-sensitive $\mathrm{K}^{+}$conductance, suggesting that $\mathrm{P} 2 \mathrm{X}_{\mathrm{f}}$ plays a role in $\mathrm{K}^{+}$channel regulation. In addition, ATP/ADP apyrase and inhibitors of $\mathrm{P} 2 \mathrm{X}_{\mathrm{f}}$ inhibited regulatory volume decrease (RVD). These data are consistent with the presence of a $\mathrm{P} 2 \mathrm{X}$ receptor that plays a role in the regulation of cell volume and $\mathrm{K}^{+}$channels in frog renal proximal tubule cells.
\end{abstract}

Keywords Purinergic receptor physiology in epithelia . Renal physiology · Ion channel · Potassium ion channel · Volume regulation in epithelial cells

Electronic supplementary material The online version of this article (doi:10.1007/s00232-010-9308-8) contains supplementary material, which is available to authorized users.

J. P. Davies · L. Robson ( ()

Department of Biomedical Science, University of Sheffield,

Sheffield S10 2TN, UK

e-mail: 1.robson@sheffield.ac.uk

\section{Introduction}

P2 purinoceptors are a class of ATP-activated receptors that play a critical role in a variety of cellular processes in both electrically excitable and nonexcitable cells. They are subdivided into two distinct classes, P2X and P2Y receptors (Burnstock and Kennedy 1985; North and Barnard 1997). P2X receptors are ATP-gated, nonselective, $\mathrm{Ca}^{2+}$ permeable cation channels that, on activation, allow extracellular $\mathrm{Ca}^{2+}$ to enter the cell, leading to a rise in intracellular $\mathrm{Ca}^{2+}$. The P2Y receptors are $\mathrm{G}$ protein-coupled. On activation, some $\mathrm{P} 2 \mathrm{Y}$ receptors cause a rise in intracellular $\mathrm{Ca}^{2+}$, via the release of $\mathrm{Ca}^{2+}$ from intracellular stores.

At the molecular level a number of mammalian P2X and $\mathrm{P} 2 \mathrm{Y}$ receptors have been identified, $\mathrm{P}_{2} \mathrm{X}_{1-7}$ and P2Y $1,2,4,6,11-14$, with only two amphibian P2X receptors

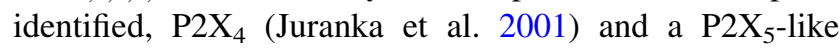
current (Jensik et al. 2001). These receptors can act as homomeric channels and form heteromeric channels. To date, in heterologous systems, combinations of a number of $\mathrm{P} 2 \mathrm{X}$ receptors have been observed, including $\mathrm{P}_{2} \mathrm{X}_{2 / 3}, \mathrm{P} 2 \mathrm{X}_{1 / 5}$ and

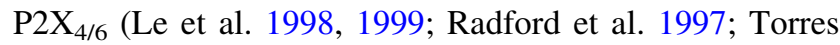
et al. 1999). There is also evidence for the presence of

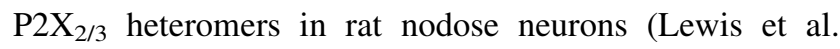
1995). A more recent study has provided evidence for $\mathrm{P} 2 \mathrm{X}_{4 / 7}$ receptors (Guo et al. 2007). The properties of these heteromers are determined by their receptor composition, with properties taken from both receptor types. This means that heteromeric channels demonstrate very different properties from the single cloned receptors.

Both P2X and P2Y family members are found in the kidney, with the majority of work on renal P2 receptors to date focusing on their role in the distal tubule and collecting duct. Previous work has demonstrated that both 
$\mathrm{P} 2 \mathrm{X}$ and $\mathrm{P} 2 \mathrm{Y}$ receptors regulate the activity of the epithelial $\mathrm{Na}^{+}$channel $(\mathrm{ENaC}) . \mathrm{P}_{2} \mathrm{Y}_{2}$ receptors inhibit $\mathrm{ENaC}$ function (Pochynyuk et al. 2008), while basolateral P2X and heteromeric $\mathrm{P} 2 \mathrm{X}_{4 / 6}$ have been shown to activate $\mathrm{ENaC}$ (Wildman et al. 2008; Zhang et al. 2007). In inner medullary collecting duct cells there is evidence for a role for $\mathrm{P}_{2} \mathrm{X}_{1}, \mathrm{P}_{2} \mathrm{X}_{3}, \mathrm{P}_{2} \mathrm{X}_{4}, \mathrm{P}_{2} \mathrm{Y}_{1}$ and $\mathrm{P}_{2} \mathrm{Y}_{2}$ (McCoy et al. 1999; $\mathrm{Xia}$ et al. 2004) in regulating $\mathrm{Na}^{+}$and $\mathrm{Cl}^{-}$transport. In addition, $\mathrm{P} 2$ receptors regulate aquaporin-2-mediated water reabsorption and $\mathrm{K}^{+}$channel activity in the collecting duct ( $\mathrm{Lu}$ et al. 2000; Wildman et al. 2009). In the thick ascending limb P2 receptors also play a regulatory role, with $\mathrm{P}_{2} \mathrm{Y}_{2}$ and an as yet unidentified $\mathrm{P} 2 \mathrm{X}$ receptor involved (Jensen et al. 2007; Silva and Garvin 2009). P2Y 2 receptors are also thought to be important in macula densa cell signaling (Liu et al. 2002) and in the modulation of apoptosis of human mesangial cells (Solini et al. 2007). In the proximal tubule a significant body of work has concentrated on $\mathrm{P} 2 \mathrm{Y}$ receptors, with molecular and functional approaches indicating the presence of $\mathrm{P} 2 \mathrm{Y}_{1}, \mathrm{P}_{2} \mathrm{Y}_{2}, \mathrm{P} 2 \mathrm{Y}_{4}$ and $\mathrm{P}_{2} \mathrm{Y}_{6}$ (Bailey 2004; Bailey et al. 2001; Cha et al. 1998; Chan et al. 1998; Lee et al. 2005). These P2Y receptors are thought to play an important role in regulating $\mathrm{Na}^{+}$-glucose transport activity, $\mathrm{HCO}_{3}{ }^{-}$reabsorption and the regulation of basolateral $\mathrm{Cl}^{-}$channels (Bailey et al. 2001; Bouyer et al. 1998; Lee et al. 2005). In contrast, very few studies have identified P2X receptors at either the molecular or the functional level in proximal tubule. The few studies completed have used cell lines and primary cultures and provide evidence for the expression of $\mathrm{P} 2 \mathrm{X}_{1}, \mathrm{P} 2 \mathrm{X}_{4}$, $\mathrm{P}_{2} \mathrm{X}_{5}$ and $\mathrm{P} 2 \mathrm{X}_{6}$ (Filipovic et al. 1998; Leipziger and Unwin 2003; Takeda et al. 1998). At a functional level, only studies in LLC-PK 1 cells have shown ATP-activated, P2Xmediated currents (Filipovic et al. 1998). In these cells, the pharmacological properties of the current were consistent with $\mathrm{P} 2 \mathrm{X}_{2}$, although RT-PCR identified a fragment that closely resembled rat $\mathrm{P} 2 \mathrm{X}_{1}$. To date, no study has shown evidence for the existence of functional $\mathrm{P} 2 \mathrm{X}$ receptors in native proximal tubule cells. Therefore, the aim of the current study was to examine the physiological function and pharmacological properties of an ATP-activated current in freshly isolated frog single proximal tubule cells.

\section{Methods}

\section{Cell Isolation}

Single proximal tubule cells were isolated from Rana temporaria using an enzyme digestion technique (Hunter 1989). Frogs were killed by stunning, and the brain and spinal cord were destroyed prior to removal of the kidneys, in accordance with U.K. legislation. Proximal tubule cells were identified by their "snowman" appearance (Robson and Hunter 1994c).

\section{Cell Length Experiments}

Cell length was measured using two different techniques that utilize changes in light intensity at the cell membrane/ bath interface. The first technique used a photodiode arraybased system as described previously (Mounfield and Robson 1998), while the second technique used a digital camera-based system (Soft Cell; Cairn Research, Kent, UK). Cells were initially superfused with frog Ringer that contained (in $\mathrm{mM}$ ) $50 \mathrm{NaCl}, 3 \mathrm{KCl}, 2 \mathrm{CaCl}_{2}, 1 \mathrm{MgCl}_{2}, 10$ HEPES (titrated to pH 7.4 using $\mathrm{NaOH}$ ) and 89 mannitol. Hypotonic shock was then induced by the removal of $40 \mathrm{mM}$ mannitol. This was repeated in unpaired cells in the presence of varying $\mathrm{P} 2 \mathrm{X}$ receptor antagonists (camerabased system) or in the presence of ATP/ADP apyrase (array-based system), which breaks down ATP. Thus, if ATP release is important in volume regulation, then ATP/ ADP apyrase should inhibit the regulatory response. Antagonist or apyrase was present in both control and hypotonic solutions. All test solutions were compared to day-matched controls.

\section{Patch Experiments}

Approximately $20 \mu \mathrm{l}$ of the cell suspension was placed in a Perspex bath on the stage of an inverted microscope (IX70; Olympus, Tokyo, Japan). Standard patch-clamp techniques were employed to investigate whole-cell currents (Hamill et al. 1981), with voltage protocols driven from a computer equipped with a Digidata interface (Axon Instruments, Foster City, CA). Data were obtained and analyzed using pClamp (Axon Instruments). Recordings were made using a List EPC-7 amplifier (HEKA, Lambrecht, Germany). On achieving the whole-cell configuration via the basolateral aspect of the cell, currents were saved directly onto the hard disk of the computer following low-pass filtering at $5 \mathrm{kHz}$. Microsoft (Redmond, WA) Excel 2000 was used to determine average steady-state currents at each potential. Cell area was calculated from the capacity transients seen in response to a $20-\mathrm{mV}$ potential step, with membrane capacitance assumed to be $1 \mu \mathrm{F} / \mathrm{cm}^{2}$. Except where stated, the pipette contained a high- $\mathrm{Na}^{+}$solution (in mM) 100 $\mathrm{NaCl}, 2 \mathrm{MgCl}_{2}, 0.5$ EGTA and 10 HEPES (titrated to $\mathrm{pH}$ 7.4 with $\mathrm{NaOH}$ ) and the bath contained (in $\mathrm{mM}$ ) $100 \mathrm{NaCl}$, $0.5 \mathrm{CaCl}_{2}, 0.5 \mathrm{MgCl}_{2}$ and 10 HEPES (titrated to $\mathrm{pH} 7.4$ with $\mathrm{NaOH}$ ). In experiments investigating the properties of the ATP-activated current, the total ATP added to the extracellular solution was adjusted to give a constant free ATP concentration between control and test conditions (Maxchelator, maxchelator.stanford.edu). For higher 
concentrations of agonists, osmolality was maintained by substitution of mannitol.

Two different voltage-clamp approaches were used. In one set of experiments clamp potential was held constant at $-100 \mathrm{mV}$ and changes in current at this potential were recorded over time. At various time points potential was ramped to between -100 and $+20 \mathrm{mV}$. In the second set of experiments whole-cell potential was clamped at $-40 \mathrm{mV}$ and then stepped to between +20 and $-100 \mathrm{mV}$ in $-20 \mathrm{mV}$ steps. The reversal potential $\left(V_{\text {rev }}\right)$ of currents obtained using this voltage protocol was determined using polynomial regression analysis. The ATP-activated conductance $\left(G_{\mathrm{ATP}}\right)$ was taken over the potential range -100 to $-20 \mathrm{mV}$. For $\mathrm{K}^{+}$current studies, outward $\left(G_{\text {out }}\right)$ and inward $\left(G_{\text {in }}\right)$ chord conductances were calculated from outward and inwardly directed currents, respectively.

\section{Effect of ATP and BzATP}

Patches were exposed to $100 \mu \mathrm{M}, 200 \mu \mathrm{M}, 500 \mu \mathrm{M}$ and

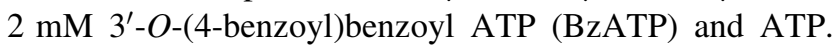
The order of exposure to the two agonists was varied to ensure that there was no effect of desensitization. To examine possible desensitization, whole-cell patches were exposed to an agonist (either $2 \mathrm{mM}$ BzATP or $500 \mu \mathrm{M}$ ATP) three times. The dose response to these agonists was determined using the following bath solution (in $\mathrm{mM}$ ): 85 $\mathrm{NaCl}, 0.5 \mathrm{CaCl}_{2}, 0.1 \mathrm{MgCl}_{2}, 25$ mannitol and 10 HEPES (titrated to $\mathrm{pH} 7.4$ with $\mathrm{NaOH}$ ). Cells were exposed to either ATP or BzATP $(10,8,4,2,1$ and $0.5 \mathrm{mM})$.

\section{Agonist Potency and Effect of Antagonists}

Patches were exposed to $500 \mu \mathrm{M}$ ATP, followed by $500 \mu \mathrm{M}$ of a second agonist, either BzATP, 2-methylthio ATP (2-MeSATP) or $\alpha, \beta$ methylene ATP ( $\alpha \beta$-MeATP). To examine the effect of antagonists, patches were exposed to $500 \mu \mathrm{M}$ ATP alone, then ATP in the presence of one of the following P2X receptor antagonists: suramin, $2^{\prime}, 3^{\prime}-$ $O$-(2,4,6-trinitrophenyl)-ATP (TNP-ATP) or pyridoxal5-phosphate-6-azophenyl-2' 4' $^{\prime}$-disulfonic acid (PPADS). The effect of the $\mathrm{P} 2 \mathrm{X}_{7}$ antagonists brilliant blue $\mathrm{G}$ (BBG) (Jiang et al. 2000) and KN-62 (Humphreys et al. 1998) were examined by exposing patches to $2 \mathrm{mM}$ BzATP and then BzATP in the presence of the antagonist.

\section{Current Properties and Relative Permeability of ATP-Activated Current}

Whole-cell patches were obtained with the standard high$\mathrm{Na}^{+}$pipette solution. The bath contained (in $\mathrm{mM}$ ) $100 \mathrm{NaCl}$, $0.5 \mathrm{CaCl}_{2}, 0.1 \mathrm{MgCl}_{2}$ and $10 \mathrm{HEPES}$ (titrated to $\mathrm{pH} 7.4$ with $\mathrm{NaOH}$ ). Current activation was achieved using $2 \mathrm{mM}$ ATP.
To examine the effect of ivermectin, an antiparasitic agent known to enhance activation of $\mathrm{P}_{2} \mathrm{X}_{4}$ (Priel and Silberberg 2004), whole-cell patches were obtained with a bath solution containing (in $\mathrm{mM}$ ) $20 \mathrm{NaCl}, 0.5 \mathrm{CaCl}_{2}, 0.1$ $\mathrm{MgCl}_{2}, 160$ mannitol and 10 HEPES (titrated to $\mathrm{pH} 7.4$ with $\mathrm{NaOH}$ ). The effect of $10 \mu \mathrm{M}$ ivermectin was determined in paired cells, with patches exposed to $2 \mathrm{mM}$ ATP initially and then after incubation with ivermectin for 1 min.

To determine the cation to anion permeability ratio, a dilution protocol was used. ATP-activated currents were recorded in paired cells in both 100 and $20 \mathrm{mM} \mathrm{NaCl}$. Osmolality was maintained by the addition of $160 \mathrm{mM}$ mannitol to the $20 \mathrm{mM}$ solution. The junction potential shift induced by reducing bath $\mathrm{NaCl}$ fivefold was measured using a flowing $3 \mathrm{M} \mathrm{KCl}$ reference electrode, and all $20 \mathrm{mM} \mathrm{NaCl} V_{\text {rev }}$ values were corrected for this value. The monovalent cation permeability ratio was determined in paired cells by substituting $100 \mathrm{mM} \mathrm{NaCl}$ with either $\mathrm{RbCl}, \mathrm{CsCl}$ or $\mathrm{LiCl}$. To determine the relative permeability for $\mathrm{Na}^{+}$to $\mathrm{NMDG}^{+}$, whole-cell patches were obtained with $100 \mathrm{mM} \mathrm{NaCl}, 0.5 \mathrm{mM}$ EGTA and $10 \mathrm{mM}$ HEPES (titrated to $\mathrm{pH} 7.4$ using $\mathrm{NaOH}$ ) in the pipette and $100 \mathrm{mM}$ NMDG-Cl and $10 \mathrm{mM}$ HEPES (titrated to $\mathrm{pH} 7.4$ using $\mathrm{NMGD}^{+}$) in the bath. The ATP-activated current was determined (addition of $4 \mathrm{mM}$ ATP to the bath). To determine the $\mathrm{Ca}^{2+}$ to $\mathrm{Na}^{+}$permeability ratio, the extracellular solution was then exchanged for one that contained $5 \mathrm{mM} \mathrm{CaCl}_{2}$, in addition to NMDG-Cl and HEPES. For all permeability ratio calculations the Goldman-Hodgkin-Katz voltage equation was used, with a modified form utilized in the $\mathrm{Ca}^{2+}$ to $\mathrm{Na}^{+}$calculation (Laycock et al. 2009).

\section{Effect of Extracellular Cations}

The bath contained (in $\mathrm{mM}$ ) $100 \mathrm{NaCl}$ and 10 HEPES (titrated to $\mathrm{pH} 7.4$ with $\mathrm{NaOH}$ ). Patches were exposed to $2 \mathrm{mM}$ ATP under the control circumstance and then in the presence of either $100 \mu \mathrm{M} \mathrm{Zn}^{2+}$ or $50 \mu \mathrm{M} \mathrm{Cu}^{2+}$. In $\mathrm{Ca}^{2+}$ experiments the effect of ATP was examined with either 0.5 (control) or 2 (test) $\mathrm{mM} \mathrm{Ca}^{2+}$ in the bath. The effect of extracellular $\mathrm{pH}$ was examined using the standard bath solution, with patches exposed to $2 \mathrm{mM}$ ATP at $\mathrm{pH} 7.4$ and either $\mathrm{pH} 6.3$ (addition of $\mathrm{HCl}$ ) or $\mathrm{pH} 8.3$ (addition of $\mathrm{NaOH})$.

\section{Effect of P2X Activation on Whole-Cell $\mathrm{K}^{+}$Conductance}

To determine the effect of activation of the frog P2X receptor on $\mathrm{K}^{+}$channels, whole-cell $\mathrm{K}^{+}$currents were measured in the absence and presence of ATP. The pipette contained (in $\mathrm{mM}$ ) $100 \mathrm{KCl}, 2 \mathrm{MgCl}_{2}, 10 \mathrm{HEPES}$ (titrated to $\mathrm{pH} 7.4$ with $\mathrm{KOH}$ ) and 0.25 EGTA as well as 25 units $/ \mathrm{ml}$ 
alkaline phosphatase, which was included to reduce $\mathrm{K}^{+}$ channel rundown. The bath contained (in $\mathrm{mM}$ ) $92 \mathrm{NaCl}, 3$ $\mathrm{KCl}, 1 \mathrm{CaCl}_{2}, 0.5 \mathrm{MgCl}_{2}, 10 \mathrm{HEPES}$ (titrated to $\mathrm{pH} 7.4$ with $\mathrm{NaOH})$ and 20 mannitol. On achieving the whole-cell configuration, $1 \mathrm{mM}$ quinidine was added to the bath and the current sensitive to quinidine was taken as the magnitude of the $\mathrm{K}^{+}$currents. Quinidine has previously been shown to inhibit two $\mathrm{K}^{+}$-selective currents in frog renal proximal tubule cells (Robson and Hunter 1997). The quinidine-sensitive current was then determined again after 5 min. To examine the effect of $\mathrm{P} 2 \mathrm{X}$ receptor activation, whole-cell patches were obtained as described previously. However, after the first exposure to quinidine and subsequent wash, cells were exposed to $4 \mathrm{mM}$ ATP. ATP was left in the bath for $5 \mathrm{~min}$, and the quinidine-sensitive current was determined after this time.

\section{Chemicals and Solutions}

The osmolality of all solutions was measured (Roebling osmometer) and adjusted to within $1 \mathrm{mosmol} / \mathrm{kg}$ water of $215 \mathrm{mosmol} / \mathrm{kg}$ water with water or mannitol as appropriate. Chemicals were obtained from Sigma (St. Louis, MO) and were of analytical grade.

\section{Statistics}

Results are given as means \pm 1 SEM, with the number of experiments in parentheses. Except where stated in the text, significance was tested using paired Student's $t$-test. Additional tests included unpaired Student's $t$-test, ANOVA, Fisher's exact probability test and correlation coefficient as appropriate. For all, significance was assumed at the $5 \%$ level.

\section{Results}

\section{Effect of ATP and BzATP}

Both ATP and BzATP increased whole-cell currents at $-100 \mathrm{mV}$, although ATP gave a greater increase compared to BzATP. ATP increased whole-cell currents at all concentrations tested $(P \leq 0.001$ for all). BzATP increased whole-cell currents at $2 \mathrm{mM}(P=0.004)$ and $500 \mu \mathrm{M}$ $(P=0.0004)$ but was without effect at $200 \mu \mathrm{M}$ $(P=0.267)$ and $100 \mu \mathrm{M}(P=0.192)$. Figure $1 \mathrm{a}, \mathrm{b}$ shows typical traces from cells exposed to $500 \mu \mathrm{M}$ ATP. Mean agonist-activated currents are shown in Fig. 1c. At all concentrations the response to ATP was greater than the response to BzATP (unpaired Student's $t$-test). The BzATP and ATP activated current did not demonstrate desensitization. The $2 \mathrm{mM}$ BzATP-activated currents were
$-12.5 \pm 1.67, \quad-16.0 \pm 4.52$ and $-11.51 \pm 1.92 \mathrm{pA}$ ( $n=13$ ) for first, second and third exposures, respectively. The mean $500 \mu \mathrm{M}$ ATP activated currents were $-10.6 \pm$ $2.96,-8.77 \pm 1.78$ and $-9.08 \pm 1.23 \mathrm{pA}(n=13)$ for first, second and third exposures, respectively. There was no significant difference between these: $F_{2,36}=0.69$ and $F_{2,36}=0.23$, for BzATP and ATP, respectively (ANOVAs). There was also no correlation between current activation and exposure number $\left(r^{2}=0.04\right.$ and $\left.r^{2}=0.08\right)$.

ATP activated the whole-cell current in a dose-dependent manner (Fig. 1d). Half-maximal activation was observed with $2.77 \pm 0.24 \mathrm{mM}$ ATP $(n=9)$, with a Hill coefficient of $3.89 \pm 0.57$ and maximal current of $-30.1 \pm 3.68 \mathrm{pA} \quad\left(r^{2}=0.992 \pm 0.002\right)$. BzATP also activated the currents in a dose-dependent manner. Halfmaximal activation was observed with $4.00 \pm 0.38 \mathrm{mM}$ BzATP $(n=7)$, with a Hill coefficient of $2.00 \pm 0.07$ and maximal current of $-32.1 \pm 2.31 \mathrm{pA} \quad\left(r^{2}=0.997 \pm\right.$ 0.001). The ATP concentration required for half-maximal activation was significantly smaller than the half-maximal concentration of BzATP $(P=0.01$, unpaired Student's $t$-test). There was no significant difference between the maximal current activated by either agonist $(P=0.62$, unpaired Student's $t$-test).

\section{Agonist Potency and Effect of Antagonists}

At $500 \mu \mathrm{M}$, ATP, BzATP, 2-MeSATP and $\alpha \beta$-MeATP all increased whole-cell currents $(P \leq 0.0001)$. In paired cells the effect of ATP on whole-cell current was greater than the effect of either BzATP ( $n=12, P=0.003$ ) or 2-MeSATP ( $n=24, P<0.0005$ ) (Fig. 2). In contrast, ATP and $\alpha \beta$-MeATP increased currents by comparable amounts ( $n=13, P=0.30$ ) (Fig. 2). The agonist potency sequence was $\mathrm{ATP}=\alpha \beta$-MeATP $>\mathrm{BzATP}=2$-MeSATP. In the presence of $100 \mu \mathrm{M}$ suramin $(n=16), 30 \mathrm{nM}$ TNP-ATP $(n=16)$ or $10 \mu \mathrm{M}$ PPDAS $(n=21)$, the ATP-activated current was inhibited by $30 \%, 44 \%$ and $34 \%$, respectively ( $P<0.008$ for all) (Fig. 3). The inhibition by suramin and PPADS was reversible, but that by TNP-ATP was not. It has previously been demonstrated that inhibition by PPADS can be increased after incubation for $10 \mathrm{~min}$. However, in paired cells the ATP-activated current in the presence of PPADS at $1 \mathrm{~min},-9.00 \pm 1.82 \mathrm{pA}(n=9)$, was not significantly different from that at $10 \mathrm{~min},-10.2 \pm 4.12 \mathrm{pA}$ $(n=9, P=0.65)$. PPADS $(100 \mu \mathrm{M})$ inhibited the ATPactivated current by $65 \%,-11.2 \pm 1.91 \mathrm{pA}(n=9)$ vs. $-3.94 \pm 1.12 \mathrm{pA}$, in the absence and presence of PPADS, respectively $(P=0.01)$. On wash the response to ATP recovered, $-11.1 \pm 1.64 \mathrm{pA} . \mathrm{P}_{2} \mathrm{X}_{7}$ antagonists were without effect on BzATP-activated currents. BzATP increased whole-cell current by $-22.3 \pm 6.86 \mathrm{pA}(n=6)$ and $-21.9 \pm 8.41 \mathrm{pA}$ in the absence and presence of $\mathrm{BBG}$, 

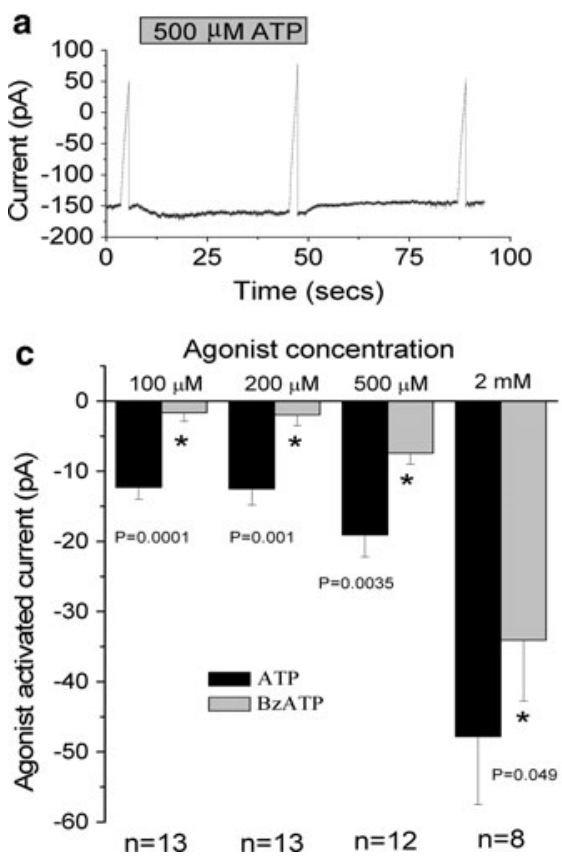

Fig. 1 Effect of different concentrations of ATP and BzATP. Clamp potential was held at $-100 \mathrm{mV}$. At three time points (control, plus ATP and wash) a ramp protocol was run between -100 and $+20 \mathrm{mV}$. a A typical trace (current in picoamperes against time in seconds), showing the effect of $500 \mu \mathrm{M}$ ATP. Solid bar indicates when ATP was present in the bath. b Typical $I-V$ traces showing the current recorded under the control circumstance, in the presence of $500 \mu \mathrm{M}$ ATP and the ATP-activated current. $V c$ is the command voltage.

respectively $(P=0.91)$. In the second set of experiments, BzATP increased whole-cell current by $-32.0 \pm 7.29 \mathrm{pA}$ $(n=6)$. In the presence of $\mathrm{KN}-62$ this was unchanged, $-27.8 \pm 7.24 \mathrm{pA}(P=0.27)$.

\section{Current Properties and Relative Permeability} of ATP-Activated Current

Figure 4a shows typical traces obtained in the absence and presence of $2 \mathrm{mM}$ ATP. Addition of ATP to the bath increased whole-cell currents (Fig. 4) $(P<0.001)$. The inward chord conductance under the control circumstance was $30.2 \pm 2.66 \mu \mathrm{S} / \mathrm{cm}^{2}(n=14)$. On addition of ATP this increased to $39.7 \pm 3.18 \mu \mathrm{S} / \mathrm{cm}^{2}$, a mean increase of $9.53 \pm 0.90 \mu \mathrm{S} / \mathrm{cm}^{2}$. The ATP-activated point conductance from these 14 cells is shown in Fig. 4c. Conductance and potential demonstrated a significant negative correlation $\left(r^{2}=-0.86, P<0.05\right)$, indicating that the ATPactivated current demonstrated inward rectification. The ATP-activated current was potentiated by 1-min incubation with $10 \mu \mathrm{M}$ ivermectin. Initially, ATP increased the current at $-100 \mathrm{mV}$ from $-710 \pm 216$ to $-809 \pm 232 \mathrm{pA}$ $(n=7)$. However, after incubation of the same patches in ivermectin, the current increased from $-657 \pm 220$ to $-785 \pm 239 \mathrm{pA}(n=7)$. The mean ATP-activated current
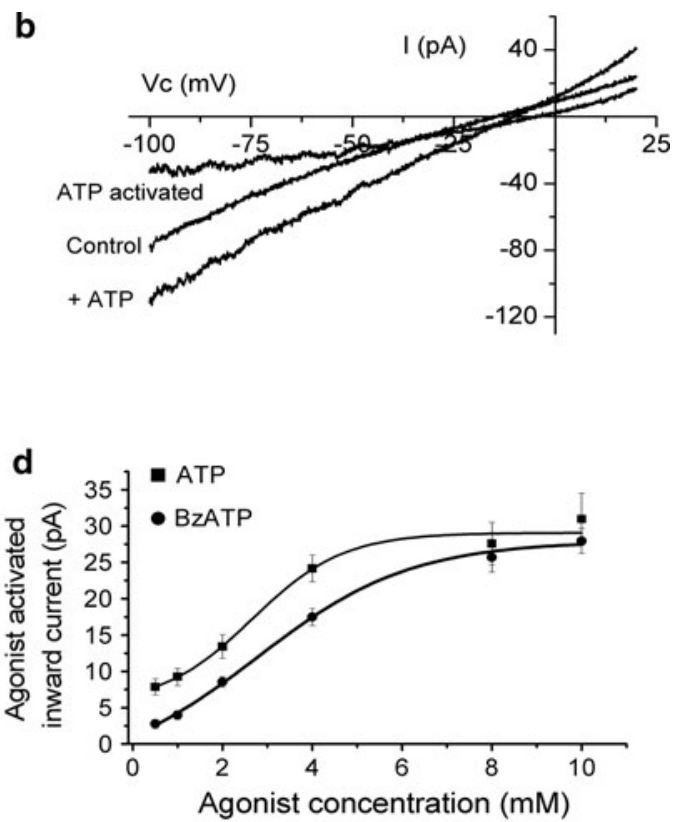

c The mean agonist-activated current in response to different concentrations of ATP and BzATP in paired cells. * Significant difference from ATP, with corresponding $P$ values given below each set of data. $n$, number of patches. d Dose response to ATP (filled square) and BzATP (filled circle). Lines through data points are the best fit to the Hill equation, $r^{2}=0.996$ and 0.998 for ATP and BzATP, respectively

in the presence of ivermectin, which enhances the activation of $\mathrm{P} 2 \mathrm{X} 4$, was significantly greater, $-98.1 \pm 23.2$ vs. $-127 \pm 23.1 \mathrm{pA}(n=7, P=0.025)$, in the absence and presence of ivermectin, respectively.

With $100 \mathrm{mM} \mathrm{NaCl}$ in the bath, the mean $V_{\text {rev }}$ of the ATP-activated current was $+1.29 \pm 2.01 \mathrm{mV}(n=10)$. On reducing bath $\mathrm{NaCl}$ to $20 \mathrm{mM} \mathrm{NaCl}$, the $V_{\text {rev }}$ shifted to $-24.4 \pm 3.26 \mathrm{mV}(P<0.001)$, a mean shift of $-25.6 \pm$ $2.27 \mathrm{mV}$. This corresponded to a cation to anion permeability ratio of $15.5 \pm 6.75$ (Fig. 5a). Substitution of $\mathrm{NaCl}$ for $\mathrm{RbCl}$ or $\mathrm{CsCl}$ shifted the $V_{\text {rev }}$ by $+5.65 \pm 1.35 \mathrm{mV}$ $(n=9, P=0.002)$ and $+4.22 \pm 1.04 \mathrm{mV}(n=8, P=$ 0.003 ) with $\mathrm{RbCl}$ and $\mathrm{CsCl}$, respectively. $\mathrm{LiCl}$ was without effect on $V_{\text {rev }},+1.37 \pm 2.14 \mathrm{mV}(n=8, P=0.52)$. These shifts corresponded to cation to $\mathrm{Na}^{+}$selectivity ratios of $1.28 \pm 0.07,1.22 \pm 0.04$ and $1.08 \pm 0.10$, for $\mathrm{Rb}^{+}, \mathrm{Cs}^{+}$ and $\mathrm{Li}^{+}$, respectively. The $V_{\text {rev }}$ of the ATP-activated current with $\mathrm{Na}^{+}$in the pipette and $\mathrm{NMDG}^{+}$in the bath was $-29.4 \pm 1.62 \mathrm{mV}(n=7)$ (Fig. $5 \mathrm{~b})$. This corresponded to an $\mathrm{NMDG}^{+}: \mathrm{Na}^{+}$permeability ratio of $0.32 \pm 0.02$. Addition of $5 \mathrm{mM} \mathrm{Ca}^{2+}$ to the extracellular solution shifted the $V_{\text {rev }}$ by $+5.72 \pm 1.90 \mathrm{mV} \quad(n=7, \quad P=0.017) \quad$ (Fig. 5c). This corresponded to a $\mathrm{Ca}^{2+}: \mathrm{Na}^{+}$permeability ratio of $6.56 \pm 2.98$. These data correspond to a selectivity sequence of $\mathrm{Ca}^{2+}>\mathrm{Rb}^{+}=\mathrm{Cs}^{+}>\mathrm{Na}^{+}=\mathrm{Li}^{+}>\mathrm{NMDG}^{+}$. 

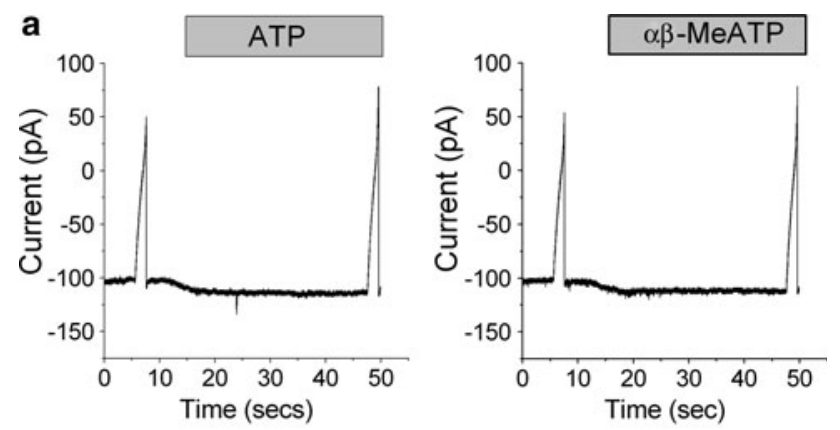

b

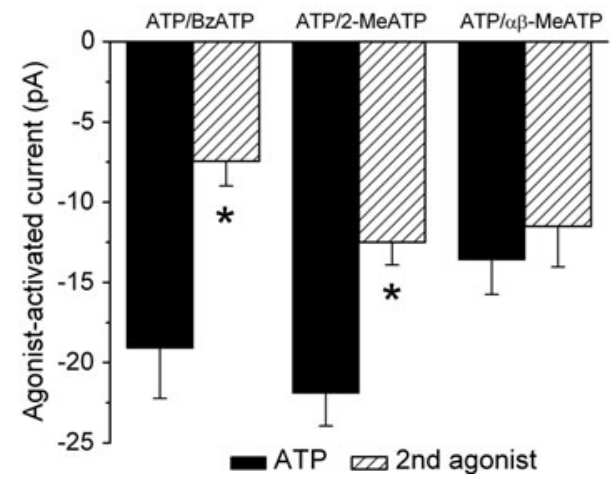

Fig. 2 Response to different P2X receptor agonists. Clamp potential was held at $-100 \mathrm{mV}$. Under control conditions and in the presence of the agonist a ramp protocol was run between -100 and $+20 \mathrm{mV}$. a Typical traces showing the effect of $500 \mu \mathrm{M}$ ATP (left) and $\alpha \beta$ MeATP (right) in the same cell. b Mean agonist-activated current at $-100 \mathrm{mV}$ in paired cells exposed to ATP and a second agonist.

* Significant difference from ATP

\section{Effect of Extracellular Cations}

$\mathrm{Zn}^{2+}$ increased the ATP-activated conductance $\left(G_{\mathrm{ATP}}\right)$ $(n=10, P=0.004)$ (Fig. 6). The $\mathrm{Zn}^{2+}$-mediated enhancement of $G_{\mathrm{ATP}}$ was reversible, with $G_{\mathrm{ATP}}$ returning to pre$\mathrm{Zn}^{2+}$ levels on washout. In the $\mathrm{Cu}^{2+}$ experiments the effect of ATP was attenuated $(n=7, P=0.003)$ (Fig. 6). The $\mathrm{Cu}^{2+}$-mediated inhibition of $G_{\text {ATP }}$ was reversible, with $G_{\text {ATP }}$ retuning to pre- $\mathrm{Cu}^{2+}$ levels on washout. With $0.5 \mathrm{mM} \mathrm{Ca}^{2+}$ in the bath $G_{\text {ATP }}$ was $6.24 \pm 0.74 \mu \mathrm{S} / \mathrm{cm}^{2}$ $(n=16)$. This was significantly reduced when bath $\mathrm{Ca}^{2+}$ was increased to $2 \mathrm{mM}(P=0.03)$ (Fig. 6). However, this reduction in $G_{\text {ATP }}$ was not reversible. Acidification inhibited, while alkalinization activated, $G_{\mathrm{ATP}}$ (mean data shown in Table 1).

\section{Effect of P2X Activation on Whole-Cell $\mathrm{K}^{+}$ Conductance}

Whole-cell potential was clamped at $-40 \mathrm{mV}$ and then stepped to between +20 and $-100 \mathrm{mV}$ in $-20-\mathrm{mV}$ steps. In control cells at time zero, quinidine inhibited a whole-cell current, $I_{\text {Quin }}($ Fig. 7a) $(P<0.001)$. The quinidine-sensitive outward and inward conductances $\left(G Q_{\text {out }}\right.$ and $\left.G Q_{\text {in }}\right)$ were $7.65 \pm 1.09$ and $12.2 \pm 1.56 \mu \mathrm{S} / \mathrm{cm}^{2}$, respectively $(n=15)$. The $V_{\text {rev }}$ of $I_{\text {Quin }}$ was $-41.4 \pm 3.84 \mathrm{mV}$ (Fig. 7e), consistent with $\mathrm{K}^{+}$-selective currents. However, $I_{\text {Quin }}$ decreased after 5 min (Fig. 7b). $G Q_{\text {out }}$ and $G Q_{\text {in }}$ were significantly reduced at $5.26 \pm 0.60$ and $7.38 \pm 0.99 \mu \mathrm{S} / \mathrm{cm}^{2}$, respectively $(n=15, P<0.001)$. The $V_{\text {rev }}$ was unchanged, $-39.16 \pm 4.98 \mathrm{mV}(P=0.46)$ (Fig. 7e). In a separate population of test cells the responses to quinidine before and after the addition of ATP were determined. The initial $G Q_{\text {out }}$ and $G Q_{\text {in }}$ in the absence of ATP were $13.2 \pm 2.18$ and $23.6 \pm 3.73 \mu \mathrm{S} / \mathrm{cm}^{2}$, respectively $(n=17)$. After 5 -min exposure to ATP, these were unchanged, $G Q_{\text {out }} 9.5 \pm 1.47$ and $G Q_{\text {in }} 22.3 \pm 3.50 \mu \mathrm{S} / \mathrm{cm}^{2}(P>0.12)$ (Fig. 7f). The $V_{\text {rev }}$ of $I_{\text {Quin }}$ was $-42.3 \pm 4.07$ and $-41.8 \pm 6.49 \mathrm{mV}$, initially and after 5-min exposure to ATP, respectively $(P=0.93)$ (Fig. 7f). Addition of ATP to the extracellular solution increased the outward and inward conductances by $8.26 \pm 1.67$ and $15.7 \pm 2.20 \mu \mathrm{S} / \mathrm{cm}^{2}$, respectively, after $5 \min (n=17, P<0.0001)$ (Fig. 7c). The $V_{\text {rev }}$ of the ATPactivated current was $-25.7 \pm 4.11 \mathrm{mV}$ (Fig. $7 \mathrm{~d}$ ). This was significantly depolarized in comparison to the $V_{\text {rev }}$ of $I_{\text {Quin }}(P=0.01)$.

\section{Role of P2X Receptors in Volume Regulation}

Hypotonic shock elicited two responses, as described previously (Robson and Hunter 1994c). In 29 cells (42\%), cell length increased to a peak, with recovery observed when cells were placed back in control Ringer. These were designated "non-RVD" cells (Fig. 8a, lower trace) and represent cells that require $\mathrm{HCO}_{3}{ }^{-}$for regulatory volume decrease (RVD) (Robson and Hunter 1994c). These cells were not considered further in the context of this study. In the remaining 40 cells (58\%) cell length increased to a peak, followed by recovery toward the preshock level. These were designated "RVD" cells (Fig. 8a, upper trace). The initial length of the RVD cells was $21.2 \pm 0.34 \mu \mathrm{m}(n=40)$. Hypotonic shock increased this by $0.80 \pm 0.04 \mu \mathrm{m}(P<0.0001)$, followed by recovery. Steady-state length was $0.13 \pm 0.05 \mu \mathrm{m}$ above the preshock level at steady state after volume regulation.

A possible role for extracellular ATP in RVD was examined by exposing cells to ATP/ADP apyrase. Neither the proportion of cells undergoing RVD $(64 \%, n=7$, Fisher's exact probability test) nor the initial length of the cells $(22.4 \pm 0.76 \mu \mathrm{m}, n=7$, unpaired Student's $t$-test $)$ was different from control RVD cells. However, ATP/ADP apyrase inhibited RVD in comparison to control cells (unpaired Student's $t$-test). Figure $8 \mathrm{~b}$ shows the increase to peak and steady-state length after RVD relative to initial length for apyrase and day-matched controls (control 1).

In a second series of experiments, two types of response were observed in control cells, as described previously, 
Fig. 3 Effect of antagonists on the $500 \mu \mathrm{M}$ ATP-activated current. Cells were held at $-100 \mathrm{mV}$ and then exposed to $500 \mu \mathrm{M}$ ATP in the absence and then the presence of the antagonist. This was followed by a second control exposure to ATP after washout of the antagonist. a-c Typical wholecell traces at $-100 \mathrm{mV}$ from three different cells in the absence and presence of $100 \mu \mathrm{M}$ suramin, $30 \mathrm{nM}$ TNP-ATP or $10 \mu \mathrm{M}$ PPADS, respectively. Arrows indicate when $500 \mu \mathrm{M}$ ATP was added to the bath. d Mean ATPactivated currents. * Significant reduction compared to the first response to ATP. Black bars indicate ATP, hatched bars indicate ATP plus antagonist and gray bars indicate ATP

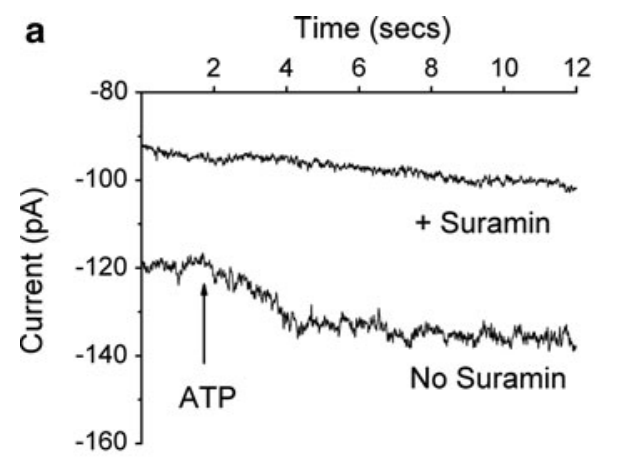

b Time (secs)

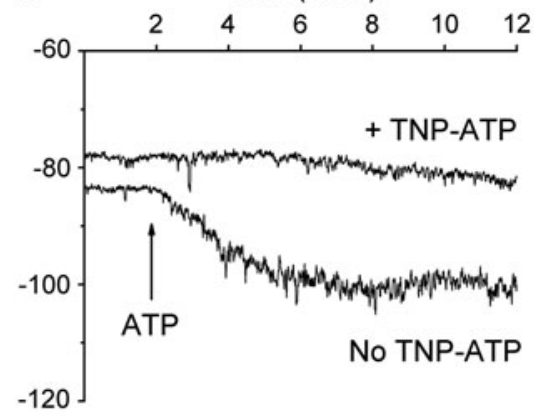

c

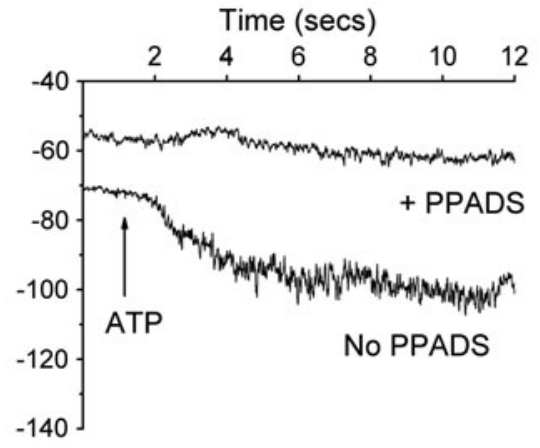

d

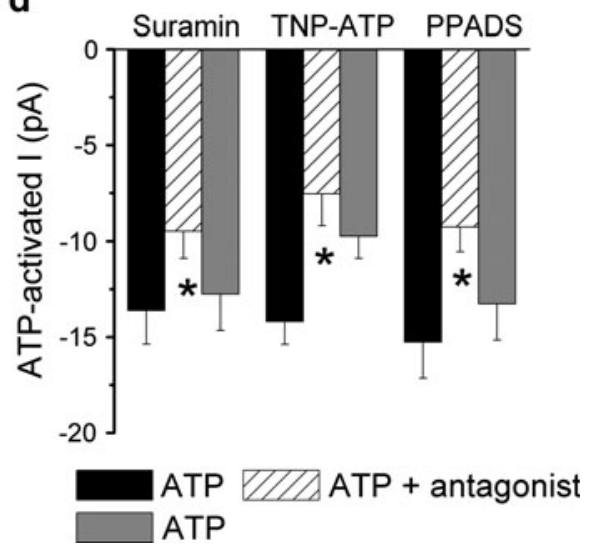

a

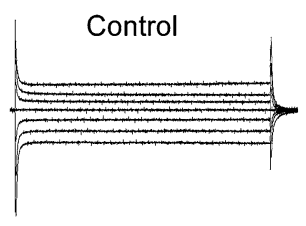

b

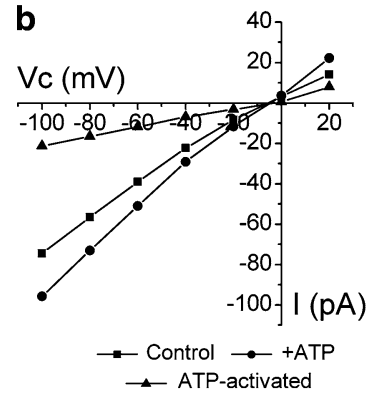

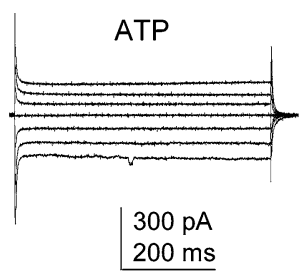

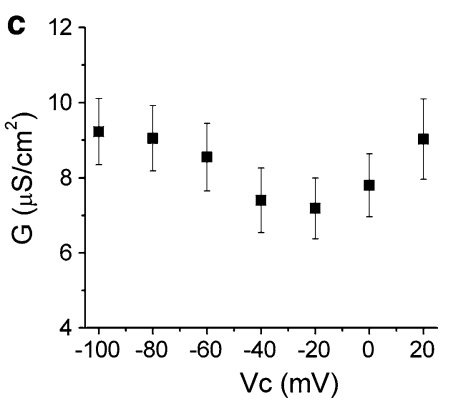

Fig. 4 Effect of ATP on whole-cell currents. Cells were clamped at $-40 \mathrm{mV}$ and then potential stepped to between +20 and $-100 \mathrm{mV}$ in $-20-\mathrm{mV}$ steps. a Typical traces obtained from the same cell in the absence (left) and presence (right) of $2 \mathrm{mM}$ ATP. b $I-V$ curves generated from the traces shown in a. $V c$ is the command voltage. c Mean point conductance of the ATP-activated currents $(n=14)$

RVD (47\%) and non-RVD cells (53\%). In RVD cells initial length was $22.2 \pm 0.46 \mu \mathrm{m}(n=22)$. On exposure to a hypotonic shock, length increased by $0.66 \pm 0.04 \mu \mathrm{m}$, to a

peak of $22.9 \pm 0.48 \mu \mathrm{m}(P<0.001)$, followed by RVD. Length was $0.06 \pm 0.08 \mu \mathrm{m}$ above the preshock level at steady state after volume regulation. Under the experimental conditions the proportions of cells undergoing RVD were $75 \%$ (21) for $100 \mu \mathrm{M}$ suramin, $63 \%$ (12) for $10 \mu \mathrm{M}$ PPADS and $61 \%$ (14) for $30 \mathrm{nM}$ TNP-ATP. The number of RVD cells was significantly increased for suramin but not PPADS or TNP-ATP (Fisher's exact probability test). The initial lengths of RVD cells were $22.9 \pm 0.47(n=21)$, $21.7 \pm 1.06$ and $22.2 \pm 0.54(n=14) \mu \mathrm{m}$ in the presence of suramin, PPADS and TNP-ATP, respectively. Figure $8 \mathrm{~b}$ shows the increase to peak and steady-state length after RVD relative to initial length for all experimental conditions. Suramin, TNP-ATP and PPADS all inhibited RVD in comparison to the control circumstance, $F_{3,65}=5.57$ (all tested using ANOVA).

\section{Discussion}

These data provide evidence for the functional expression of a P2X-like current in frog renal proximal tubule cells, $\mathrm{P} 2 \mathrm{X}_{\mathrm{f}} . \mathrm{P} 2 \mathrm{X}_{\mathrm{f}}$ was cation-selective, did not discriminate well between monovalent cations, had a poor permeability to NMDG and was around six times more permeable for $\mathrm{Ca}^{2+}$ over $\mathrm{Na}^{+}$. It was activated by a variety of P2X agonists, 
a

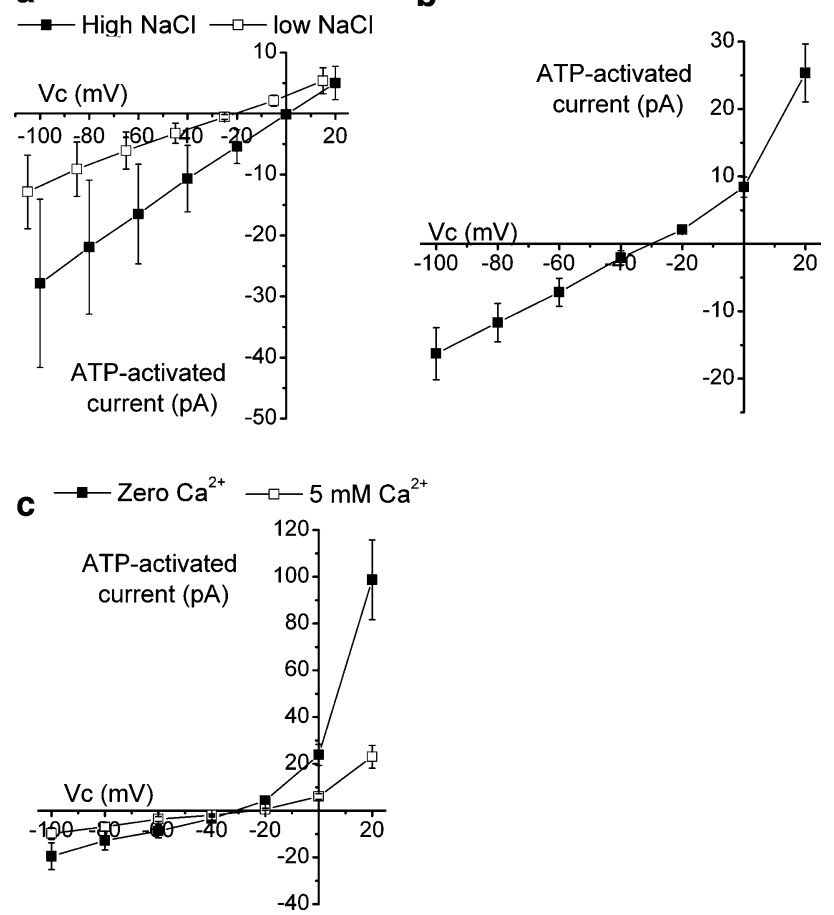

Fig. 5 Selectivity of ATP-activated current. Cells were clamped at $-40 \mathrm{mV}$ and then potential stepped to between +20 and $-100 \mathrm{mV}$ in $-20-\mathrm{mV}$ steps. $V c$ is the command voltage. a Mean currents recorded in high (filled square) or low (open square) $\mathrm{NaCl}$ in paired cells $(n=10)$. Note the shift along the $x$ axis of the low- $\mathrm{NaCl}$ data due to junction potential correction. b Mean ATP-activated current recorded with $\mathrm{NaCl}$ in the pipette and NMDG-Cl in the bath $(n=7)$. $\mathbf{c}$ Mean ATP-activated currents recorded with bath NMDG-Cl in the absence of $\mathrm{Ca}^{2+}$ (filled square) or in the presence of $5 \mathrm{mM} \mathrm{Ca}^{2+}$ (open square $)$ in paired cells $(n=7)$

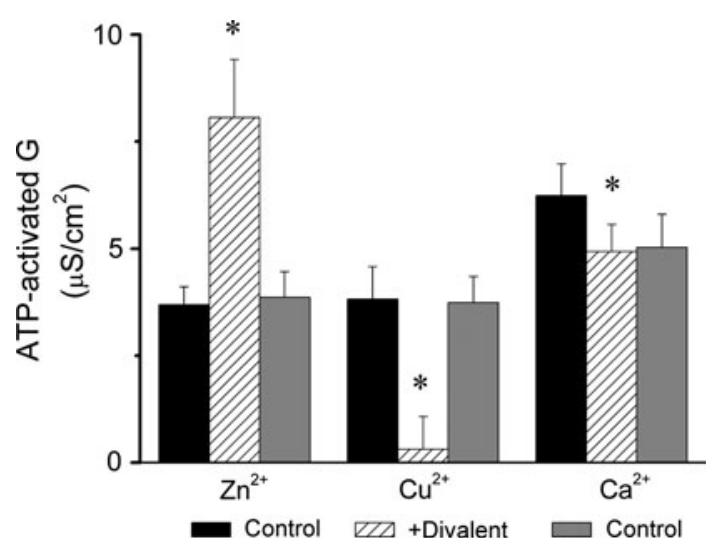

Fig. 6 Effect of divalent cations on $G_{\mathrm{ATP}}$. Cells were clamped at $-40 \mathrm{mV}$ and then potential stepped to between +20 and $-100 \mathrm{mV}$ in $-20-\mathrm{mV}$ steps. The graph shows the effect of $\mathrm{Zn}^{2+}, \mathrm{Cu}^{2+}$ and $\mathrm{Ca}^{2+}$.

* Significantly different response from ATP in the presence of the divalent cation. Black bars indicate ATP, hatched bars indicate ATP plus divalent cation and gray bars indicate ATP including ATP, BzATP, 2MeSATP and $\alpha \beta$-MeATP, and was sensitive to some $\mathrm{P} 2 \mathrm{X}$ antagonists. $\mathrm{P} 2 \mathrm{X}_{\mathrm{f}}$ also demonstrated inward rectification, a property shared by some P2X receptors (Evans et al. 1996). These properties are consistent with $\mathrm{P} 2 \mathrm{X}_{\mathrm{f}}$ being attributable to a $\mathrm{P} 2 \mathrm{X}$ receptor. However, one difference from $\mathrm{P} 2 \mathrm{X}$ receptors was that it was activated only by high concentrations of extracellular ATP, $100 \mu \mathrm{M}$ to $10 \mathrm{mM}$. In contrast, most of the cloned $\mathrm{P} 2 \mathrm{X}$ receptors require only micromolar levels of ATP (Torres et al. 1998; Valera et al. 1994; Virginio et al. 1998b), although $\mathrm{P}_{2} \mathrm{X}_{7}$ is activated by high levels of ATP (Rassendren et al. 1997). Consistent with LLC-PK $_{1}$ cells (Filipovic et al. 1998), activation of $\mathrm{P}_{2} \mathrm{X}_{\mathrm{f}}$ was observed with $100 \mu \mathrm{M}$ ATP, although maximal activation required millimolar levels. The reason for this difference is not clear, but it may reflect the fact that the current study involves an amphibian $\mathrm{P} 2 \mathrm{X}$ receptor. Certainly, a study on cloned Xenopus $\mathrm{P}^{2} \mathrm{X}_{4}$ also used high concentrations of ATP (Juranka et al. 2001). In addition, frog P2X receptors in aorta require similarly high concentrations of agonists for activation (Knight and Burnstock 1996), with maximal activation not observed with $3 \mathrm{mM}$ ATP. Alternatively, it is known that the proximal tubule membrane contains ectoATPases that break down ATP (Huang et al. 2006). Therefore, another explanation could be that the ATP in the extracellular solution next to the membrane was at a lower concentration than the bulk solution. The Hill coefficients for ATP and BzATP were similar to other studies (Jiang et al. 2003), with the larger coefficient for ATP suggesting greater cooperativity of binding compared to BzATP. In terms of the in vivo luminal ATP concentration in the proximal tubule, there is a general lack of information, with one study suggesting a maximal concentration of around $275 \mathrm{nmol} / \mathrm{l}$ in rats (Vekaria et al. 2006). This concentration would not be sufficient to activate $\mathrm{P} 2 \mathrm{X}_{\mathrm{f}}$ and, indeed, is also on the low side for activation of mammalian $\mathrm{P} 2 \mathrm{X}$ receptors. However, this concentration reflects the mean in the tubular fluid, and one suggestion is that ATP concentrations closer to the membrane could be much higher. If this is the case, then it is possible that sufficiently high concentrations are reached for activation of both mammalian and amphibian $\mathrm{P} 2 \mathrm{X}$ receptors. In addition, as discussed later, it is clear that activation of $\mathrm{P} 2 \mathrm{X}_{\mathrm{f}}$ can impact on the physiological function of the frog renal proximal tubule.

What are the properties of $\mathrm{P} 2 \mathrm{X}_{\mathrm{f}}$, and how do these compare to the different cloned $\mathrm{P} 2 \mathrm{X}$ receptors? Two amphibian cloned receptors have been identified and show $67 \%$ homology with rat $\mathrm{P} 2 \mathrm{X}_{4}$ and $\mathrm{P} 2 \mathrm{X}_{5}$ (Jensik et al. 2001; Juranka et al. 2001). $\mathrm{P} 2 \mathrm{X}_{\mathrm{f}}$ shows some similarities to these cloned receptors and to some heteromeric mammalian receptors (Table 2). The two amphibian $\mathrm{P} 2 \mathrm{X}$ receptors can be activated by levels of ATP, below $100 \mu \mathrm{M}$. This is 
Table 1 Effect of extracellular $\mathrm{pH}$ on the ATP-activated current

* Significant difference from pH $7.4(P<0.029)$

\begin{tabular}{llll}
\hline$I_{\text {ATP }}-100 \mathrm{mV}(\mathrm{pA})$ & $(n=9)$ & $I_{\text {ATP }}-100 \mathrm{mV}(\mathrm{pA})$ & $(n=9)$ \\
\hline $\mathrm{pH} 7.4$ & $-21.4 \pm 2.94$ & $\mathrm{pH} 7.4$ & $-19.0 \pm 4.03$ \\
$\mathrm{pH} 6.3$ & $-12.2 \pm 2.73^{*}$ & $\mathrm{pH} 8.3$ & $-30.2 \pm 6.45^{*}$ \\
$\mathrm{pH} 7.4$ & $-20.1 \pm 4.23$ & $\mathrm{pH} 7.4$ & $-24.8 \pm 5.01$ \\
\hline
\end{tabular}

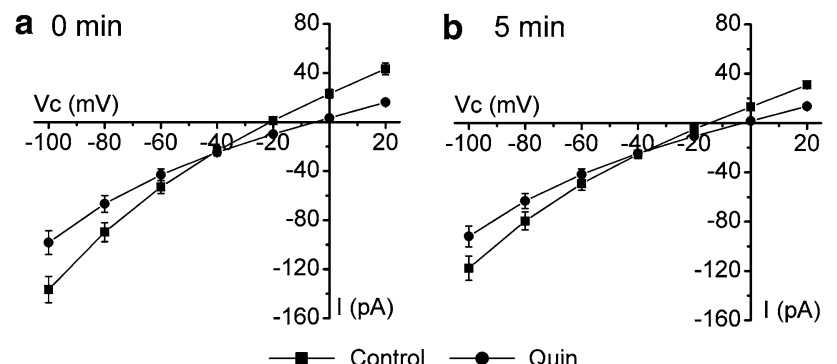

C

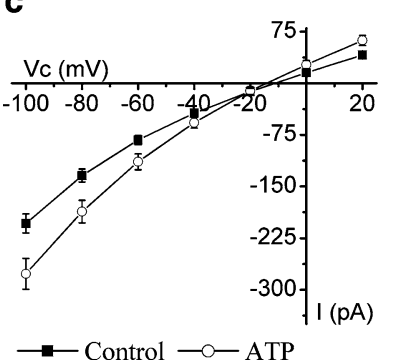

e No ATP

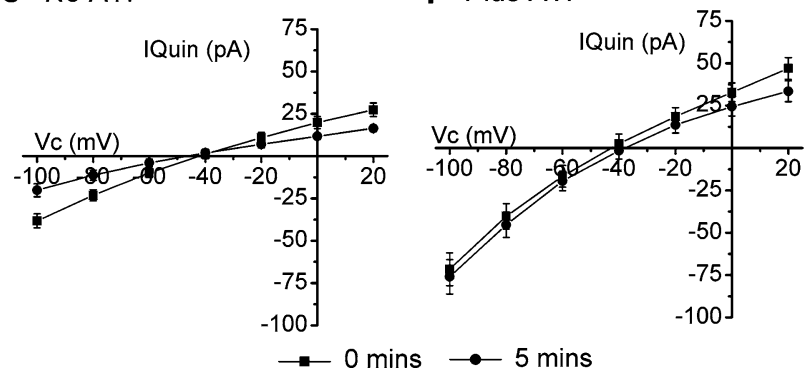

Fig. 7 Effect of quinidine and ATP on whole-cell currents. Cells were clamped at $-40 \mathrm{mV}$ and then potential stepped to between +20 and $-100 \mathrm{mV}$ in $-20-\mathrm{mV}$ steps. $V c$ is the command voltage. a, b Mean whole-cell currents recorded in the absence of ATP initially on achieving the whole-cell configuration (a) and after 5 min (b). In both figures filled square indicates currents recorded in the absence of quinidine, while filled circle indicates currents recorded in the presence of quinidine ( $n=15$ for all). c Effect of addition of extracellular ATP on mean whole-cell current. Filled square, currents recorded in the absence of ATP; open circle, currents recorded after 5-min exposure to ATP $(n=17)$. d Mean ATP-activated current. e, f Quinidine-sensitive currents in the absence of ATP (e) or presence of ATP (f). In both graphs filled square indicates currents recorded initially after achieving the whole-cell configuration, while filled circle indicates currents recorded 5 min later

different from $\mathrm{P} 2 \mathrm{X}_{\mathrm{f}}$, where $100 \mu \mathrm{M}$ ATP was needed for activation. However, as neither study performed a dose response to ATP, a definitive comparison cannot be made.
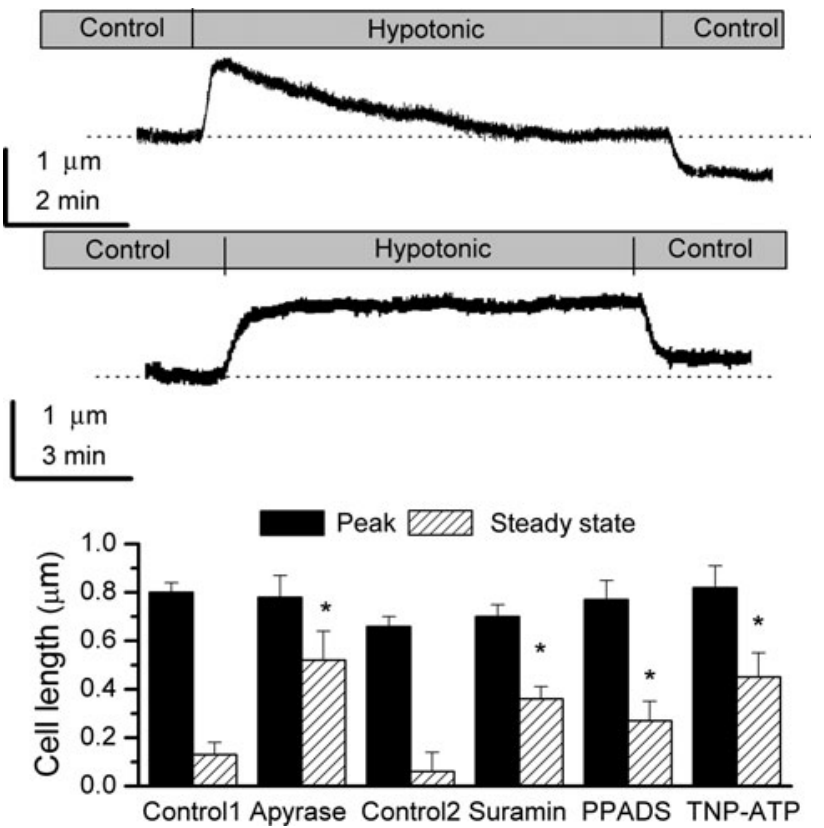

Fig. 8 Effect of P2X antagonists on RVD. a Typical cell length traces showing an RVD cell (upper) and a non-RVD cell (lower). Dotted lines represent the preshock level. b Effect of apyrase, suramin, PPADS and TNP-ATP on RVD. Data are expressed relative to control length, with 0 representing the initial preshock level. * Significant difference from the control circumstance. Controll shows day-matched data for the apyrase experiments; Control 2 shows the day-matched data for the suramin, PPADS and TNP-ATP experiments

In divalent free conditions neither cloned P2X receptor demonstrated rapid desensitization on exposure to ATP, similar to $\mathrm{P} 2 \mathrm{X}_{\mathrm{f}}$. However, although desensitization was not observed with $\mathrm{P} 2 \mathrm{X}_{\mathrm{f}}$ when bath $\mathrm{Ca}^{2+}$ was low, an apparent desensitization was observed when the cells were exposed to $2 \mathrm{mM} \mathrm{Ca}^{2+}$. Under this circumstance poor recovery of the response to ATP was observed on washout of $\mathrm{Ca}^{2+}$ from the bath. This decrease in the response to ATP during several exposures was not observed with low $\mathrm{Ca}^{2+}$ and is consistent with the $\mathrm{Ca}^{2+}$-dependent desensitization observed in amphibian $\mathrm{P} 2 \mathrm{X}$ receptors. The agonist potency sequence of $\mathrm{P} 2 \mathrm{X}_{\mathrm{f}}, \mathrm{ATP}=\alpha \beta$ meATP $>\mathrm{BzATP}=2 \mathrm{Me}-$ SATP, is similar to the frog aorta $\mathrm{P} 2 \mathrm{X}$ receptor (Knight and Burnstock 1996). This suggests that $P 2 X_{\mathrm{f}}$ is not attributable to $\mathrm{P}_{2} \mathrm{X}_{7}$ (Rassendren et al. 1997), although variations in the response to BzATP are seen at $\mathrm{P} 2 \mathrm{X}_{7}$ receptors from different species (Fonfria et al. 2008). It is therefore not 
Table 2 Comparison of the properties of $\mathrm{P} 2 \mathrm{X}_{\mathrm{f}}$ with cloned amphibian and mammalian heteromeric receptors

\begin{tabular}{|c|c|c|c|c|c|c|c|}
\hline & Amphibian $\mathrm{P} 2 \mathrm{X}_{4}$ & Amphibian $\mathrm{P} 2 \mathrm{X}_{5}$ & $\mathrm{P} 2 \mathrm{X}_{2 / 3}$ & $\mathrm{P} 2 \mathrm{X}_{1 / 4}$ & $\mathrm{P} 2 \mathrm{X}_{1 / 5}$ & $\mathrm{P} 2 \mathrm{X}_{4 / 6}$ & References \\
\hline Agonist potency & & $\mathrm{X}$ & $\diamond$ & $\diamond$ & $\diamond$ & $\mathrm{X}$ & Jensik et al. (2001) \\
\hline Suramin & & $>$ & $>$ & $>$ & $>$ & $\overrightarrow{40 \%}$ & $\begin{array}{l}\text { Juranka et al. (2001) } \\
\text { Le et al. (1998) }\end{array}$ \\
\hline PPADS & $\diamond$ & $>$ & $>$ & $>$ & $>$ & $\diamond$ & Le et al. (1999) \\
\hline TNP-ATP & & & $>$ & $>$ & $>$ & & Liu et al. (2001) \\
\hline $\mathrm{Zn}^{2+}$ & & & $\bullet$ & & & $\diamond$ & Nicke et al. (2005) \\
\hline $\mathrm{Ca}^{2+}$ & & $\diamond$ & $\bullet$ & & $X$ & & Stoop et al. (1997) \\
\hline $\mathrm{pH}$ & & & $\mathrm{X}$ & & $\diamond$ & $\diamond$ & $\begin{array}{l}\text { Virginio et al. (1998a) } \\
\text { Wildman et al. (1998) }\end{array}$ \\
\hline
\end{tabular}

Percentages indicate percentage inhibition values close to those observed for $\mathrm{P} 2 \mathrm{X}_{\mathrm{f}}$

$\diamond$, Similarity to $\mathrm{P} 2 \mathrm{X}_{\mathrm{f}} ; \mathrm{X}$, difference; $>$, higher sensitivity; blank, not known

possible to absolutely rule out $\mathrm{P} 2 \mathrm{X}_{\mathrm{f}}$ being attributable to a $\mathrm{P} 2 \mathrm{X}_{7}$-like receptor, although the $\mathrm{P} 2 \mathrm{X}_{7}$ antagonists $\mathrm{KN}-62$ and $\mathrm{BBG}$ were without effect on $\mathrm{P} 2 \mathrm{X}_{\mathrm{f}}$ (Humphreys et al. 1998; Jiang et al. 2000). $\mathrm{P}_{2} \mathrm{X}_{\mathrm{f}}$ was sensitive to $100 \mu \mathrm{M}$ suramin, $10 \mu \mathrm{M}$ PPADS and $30 \mathrm{nM}$ TNP-ATP $(30 \%, 44 \%$ and $34 \%$ inhibition, respectively). This sensitivity to PPADS is similar to amphibian $\mathrm{P}^{2} \mathrm{X}_{4}$ (50\% inhibition) (Juranka et al. 2001) and P2X $\mathrm{X}_{4 / 6}$ (40\% inhibition) (Le et al. 1998), although it is different from the bullfrog $P 2 X$ receptor, which is completely blocked by both $100 \mu \mathrm{M}$ suramin and PPADS (Jensik et al. 2001). The sensitivity to PPADS was similar to amphibian $\mathrm{P}_{2} \mathrm{X}_{4}$ and $\mathrm{P} 2 \mathrm{X}_{4 / 6}$. TNPATP is a potent inhibitor of $\mathrm{P} 2 \mathrm{X}_{1 / 5}, \mathrm{P} 2 \mathrm{X}_{1 / 4}$ and $\mathrm{P} 2 \mathrm{X}_{2 / 3}$ (Le et al. 1999; Nicke et al. 2005; Virginio et al. 1998b), with $\sim 80 \%$ inhibition observed with $30 \mathrm{nM}$. This is higher than the sensitivity of $\mathrm{P} 2 \mathrm{X}_{\mathrm{f}}$. Like $\mathrm{P} 2 \mathrm{X}_{\mathrm{f}}$, the bullfrog cloned receptor also shows inhibition by $\mathrm{Ca}^{2+}$ (Jensik et al. 2001). $\mathrm{P}^{2} \mathrm{X}_{\mathrm{f}}$ was potentiated by ivermectin, which is known to enhance activation of $\mathrm{P}_{2} \mathrm{X}_{4}$ (Priel and Silberberg 2004) and was also potentiated by extracellular $\mathrm{Zn}^{2+}$ and inhibited by extracellular $\mathrm{Cu}^{2+}$ and $\mathrm{H}^{+}$.

Overall, $\mathrm{P} 2 \mathrm{X}_{\mathrm{f}}$ would appear to share greatest similarity with $\mathrm{P} 2 \mathrm{X}_{2 / 3}$ or $\mathrm{P} 2 \mathrm{X}_{4 / 6}$, although its properties are not entirely consistent with these heteromeric $\mathrm{P} 2 \mathrm{X}$ receptors. Given the fact that previous expression studies have shown the presence of $\mathrm{P} 2 \mathrm{X}_{1}, \mathrm{P} 2 \mathrm{X}_{4}, \mathrm{P} 2 \mathrm{X}_{5}$ and $\mathrm{P} 2 \mathrm{X}_{6}$ in the renal proximal tubule, it is likely that $\mathrm{P} 2 \mathrm{X}_{\mathrm{f}}$ represents a $\mathrm{P} 2 \mathrm{X}_{4 / 6^{-}}$ like $\mathrm{P} 2 \mathrm{X}$ receptor.

$\mathrm{P} 2 \mathrm{X}_{\mathrm{f}}$ is clearly a native proximal tubule $\mathrm{P} 2 \mathrm{X}$-like receptor, and on activation it would be expected to lead to an influx of $\mathrm{Ca}^{2+}$ into the cell. However, the magnitude of the $\mathrm{P} 2 \mathrm{X}_{\mathrm{f}}$-mediated currents was small. In comparison to $\mathrm{P} 2 \mathrm{X}$ receptor expression studies this is to be expected as in those studies the magnitude of the P2X currents reflects the fact that the channels have been overexpressed. Looking at studies of native $\mathrm{P} 2 \mathrm{X}$ receptor currents provides a variable picture in terms of current magnitude. In $\mathrm{LLC}^{-\mathrm{PK}_{1}}$ cells, currents were on the order of a few hundred picoamperes (Filipovic et al. 1998). In contrast, studies in neurons, airway ciliated cells and Leydig cells show small P2Xmediated currents, similar to $\mathrm{P}^{2} \mathrm{X}_{\mathrm{f}}$ (Chaves et al. 2006; Ma et al. 2006; Mori et al. 2001). It is clear, therefore, that physiologically relevant $\mathrm{P} 2 \mathrm{X}$ native currents can be small. What is the physiological role of $\mathrm{P} 2 \mathrm{X}_{\mathrm{f}}$ in the renal proximal tubule? The data presented in the current study suggest that $\mathrm{P} 2 \mathrm{X}_{\mathrm{f}}$ plays an important role in volume regulation and $\mathrm{K}^{+}$channel activation.

Frog proximal tubule cells have the ability to regulate their volume in response to cell swelling, RVD (Robson and Hunter 1994c). Such volume regulation plays an important role in diverse cellular process such as cell growth and proliferation, osmoregulation and cellular metabolism. There is a clear role for $\mathrm{P} 2$ activation in regulating proximal tubule cell proliferation (Lee and Han 2006), while a role for $\mathrm{P} 2$ receptor activation in RVD in hepatocytes has been proposed (Wang et al. 1996). This suggests that $\mathrm{P} 2$ receptors and volume regulation may be important for normal cell function. Previous work in frog proximal cells has demonstrated a role for $\mathrm{K}^{+}$and $\mathrm{Cl}^{-}$ channels in RVD (Robson and Hunter 1994c, 2005). Whole-cell patch-clamp experiments have identified barium-sensitive $\mathrm{K}^{+}$and DIDS-sensitive $\mathrm{Cl}^{-}$currents that are volume sensitive (Robson and Hunter 1994a, 2005). Unpublished studies demonstrate that quinidine-sensitive $\mathrm{K}^{+}$currents are also volume-sensitive, with quinidinesensitive conductance reduced in the presence of a hypertonic bath solution $\left(19.2 \pm 4.38\right.$ vs. $7.31 \pm 1.46 \mu \mathrm{S} / \mathrm{cm}^{2}$ in the presence of control and hypertonic solutions, respectively, $n=12$ for each group). For the $\mathrm{Cl}^{-}$channels volume activation is mediated by protein kinase C (PKC) (Robson and Hunter 1994a). The mechanism underlying volume regulation of the $\mathrm{K}^{+}$currents has not been 
elucidated but does not appear to involve PKC. In addition, RVD is inhibited in the absence of extracellular $\mathrm{Ca}^{2+}$, consistent with a $\mathrm{Ca}^{2+}$ influx pathway playing a critical role (Robson and Hunter 1994c). The specific mechanism by which $\mathrm{Ca}^{2+}$ enters the renal proximal is unknown; however, a number of candidates have been proposed. One of these is stretch-activated, $\mathrm{Ca}^{2+}$-permeable cation channels (SACs), as the SAC inhibitor gadolinium $\left(\mathrm{Gd}^{3+}\right)$ blocks RVD (Robson and Hunter 1994c) and two $\mathrm{Gd}^{3+}$ and volume-sensitive cation conductances have been identified in these cells (Robson and Hunter 1994b). However, subsequent work has indicated that the volume-sensitive $\mathrm{Cl}^{-}$ channels are also inhibited by $\mathrm{Gd}^{3+}$ (Robson and Hunter 1994a). Therefore, the effect of $\mathrm{Gd}^{3+}$ on RVD could simply reflect inhibition of $\mathrm{Cl}^{-}$efflux rather than $\mathrm{Ca}^{2+}$ influx. A second possibility is that, on cell swelling, there is release of ATP from the cells, with ATP subsequently leading to $\mathrm{Ca}^{2+}$ influx via the activation of $\mathrm{P} 2 \mathrm{X}$ receptors. This is supported by the current study, which demonstrated that in the presence of apyrase RVD was inhibited, suggesting that the release and presence of ATP are important in initiating volume regulation. RVD was also inhibited by the P2X antagonists suramin, TNP-ATP and PPADS. This supports a role for $\mathrm{P} 2 \mathrm{X}$ receptor activation in RVD. The degree of inhibition of RVD was similar to that observed with $\mathrm{P} 2 \mathrm{X}_{\mathrm{f}}$.

These data support a role for $\mathrm{P} 2 \mathrm{X}_{\mathrm{f}}$ activation in RVD and suggest that it may provide the $\mathrm{Ca}^{2+}$ influx pathway. This influx of $\mathrm{Ca}^{2+}$ would be expected to activate downstream efflux pathways, such as the $\mathrm{K}^{+}$and $\mathrm{Cl}^{-}$channels described earlier. A clear link exists to activation of the $\mathrm{Cl}^{-}$channels as this is PKC-mediated. For the activation of $\mathrm{K}^{+}$channels a rise in intracellular $\mathrm{Ca}^{2+}$ could directly activate channels or work indirectly via $\mathrm{Ca}^{2+}$-dependent signalling systems. The whole-cell $\mathrm{K}^{+}$current data described here suggest that $\mathrm{P} 2 \mathrm{X}_{\mathrm{f}}$ plays an important role in the activation of quinidine-sensitive $\mathrm{K}^{+}$channels previously observed in the cells. In the absence of extracellular ATP, whole-cell quinidine-sensitive $\mathrm{K}^{+}$currents decreased over $5 \mathrm{~min}$. However, in the presence of extracellular ATP this rundown was absent, indicating that extracellular ATP was able to inhibit the rundown process. The $V_{\text {rev }}$ of the quinidine-sensitive currents, around $-40 \mathrm{mV}$, suggests that the $\mathrm{K}^{+}$channel regulated by extracellular ATP was a previously identified $\mathrm{K}^{+}$conductance (Robson and Hunter 1997). The total ATP activated current demonstrated inward rectification, similar to $\mathrm{P} 2 \mathrm{X}_{\mathrm{f}}$. Interestingly, the $V_{\text {rev }}$ of the total ATP-activated current was more positive than the $\mathrm{K}^{+}$currents but more negative than the $V_{\text {rev }}$ for $\mathrm{P} 2 \mathrm{X}_{\mathrm{f}}$. This suggests that at least part of the ATP-activated current may reflect activation of $\mathrm{K}^{+}$-selective channels. Activation of $\mathrm{K}^{+}$channels via $\mathrm{P} 2 \mathrm{X}$ receptor activation has been observed in rat osteoclasts and toad gastric smooth muscle cells (Weidema et al. 1997; Zou et al. 2001), with ${\mathrm{P} 2 \mathrm{Y}^{-}}^{-}$ mediated inhibition of $\mathrm{K}^{+}$channels in the mouse cortical collecting duct ( $\mathrm{Lu}$ et al. 2000).

In conclusion, the current study provides the first report of a native $\mathrm{P} 2 \mathrm{X}$ receptor in renal proximal tubule cells. The receptor, $\mathrm{P} 2 \mathrm{X}_{\mathrm{f}}$, was cation-selective, did not discriminate between cations and was $\mathrm{Ca}^{2+}$-permeable. $\mathrm{P} 2 \mathrm{X}_{\mathrm{f}}$ was activated by the purines $\mathrm{ATP}=\alpha \beta$ meATP $>\mathrm{BzATP}=$ 2MeSATP, did not demonstrate fast desensitization and was inhibited by suramin, PPADS and TNP-ATP. P2X $\mathrm{f}^{-}$ mediated currents were enhanced in the presence of $\mathrm{Zn}^{2+}$ or ivermectin and inhibited in the presence of $\mathrm{Cu}^{2+}$ or on acidification. These properties are consistent with $\mathrm{P} 2 \mathrm{X}_{\mathrm{f}}$ being attributable to a $\mathrm{P} 2 \mathrm{X}$ receptor and suggest that $\mathrm{P} 2 \mathrm{X}_{\mathrm{f}}$ may be attributable to a heteromeric receptor, with $\mathrm{P} 2 \mathrm{X}_{4 / 6}$ a possible candidate. The evidence presented suggests that activation of $\mathrm{P} 2 \mathrm{X}_{\mathrm{f}}$ plays a role in the regulation of cell volume and $\mathrm{K}^{+}$channels in frog renal proximal tubule cells.

Acknowledgement This work was funded by the Wellcome Trust. J. P. D. was supported by a University of Sheffield studentship.

Open Access This article is distributed under the terms of the Creative Commons Attribution Noncommercial License which permits any noncommercial use, distribution, and reproduction in any medium, provided the original author(s) and source are credited.

\section{References}

Bailey MA (2004) Inhibition of bicarbonate reabsorption in the rat proximal tubule by activation of luminal P2Y1 receptors. Am J Physiol Renal Physiol 287:F789-F796

Bailey MA, Imbert-Teboul M, Turner C, Srai SK, Burnstock G, Unwin RJ (2001) Evidence for basolateral P2Y6 receptors along the rat proximal tubule: functional and molecular characterization. J Am Soc Nephrol 12:1640-1647

Bouyer P, Paulais M, Cougnon M, Hulin P, Anagnostopoulos T, Planelles G (1998) Extracellular ATP raises cytosolic calcium and activates basolateral chloride conductance in Necturus proximal tubule. J Physiol 510:535-548

Burnstock G, Kennedy C (1985) Is there a basis for distinguishing two types of P2-purinoceptor? Gen Pharmacol 16:433-440

Cha SH, Sekine T, Endou H (1998) P2 purinoceptor localization along rat nephron and evidence suggesting existence of subtypes P2Y1 and P2Y2. Am J Physiol Renal Physiol 274:F1006-F1014

Chan CM, Unwin RJ, Bardini M, Oglesby IB, Ford APDW, Townsend-Nicholson A, Burnstock G (1998) Localization of P2X1 purinoceptors by autoradiography and immunohistochemistry in rat kidneys. Am J Physiol Renal Physiol 274:F799-F804

Chaves LAP, Pontelli EP, Varanda WA (2006) P2X receptors in mouse Leydig cells. Am J Physiol Cell Physiol 290:C1009C1017

Evans RJ, Lewis C, Virginio C, Lundstrom K, Buell G, Surprenant A, North RA (1996) Ionic permeability of, and divalent cation effects on, two ATP-gated cation channels (P2X receptors) expressed in mammalian cells. J Physiol 497:413-422 
Filipovic DM, Adebanjo OA, Zaidi M, Reeves WB (1998) Functional and molecular evidence for P2X receptors in LLC-PK1 cells. Am J Physiol Renal Physiol 274:F1070-F1077

Fonfria E, Levy DS, Goodwin JA, Roman S, Smith GD, Condreay JP, Michel AD (2008) Cloning and pharmacological characterization of the guinea pig P2X7 receptor orthologue. Br J Pharmacol 153:544-556

Guo C, Masin M, Qureshi OS, Murrell-Lagnado RD (2007) Evidence for functional P2X4/P2X7 heteromeric receptors. Mol Pharmacol 72:1447-1456

Hamill OP, Marty A, Neher E, Sakmann B, Sigworth FJ (1981) Improved patch-clamp techniques for high-resolution current recording from cells and cell-free membrane patches. Pflugers Arch 391:85-100

Huang DY, Vallon V, Zimmermann H, Koszalka P, Schrader J, Osswald H (2006) Ecto-5'-nucleotidase (cd73)-dependent and -independent generation of adenosine participates in the mediation of tubuloglomerular feedback in vivo. Am J Physiol Renal Physiol 291:F282-F288

Humphreys BD, Virginio C, Surprenant A, Rice J, Dubyak GR (1998) Isoquinolines as antagonists of the P2X7 nucleotide receptor: high selectivity for the human versus rat receptor homologues. Mol Pharmacol 54:22-32

Hunter M (1989) Isolation of single proximal cells from frog kidneys. J Physiol 416:13P

Jensen MEJ, Odgaard E, Christensen MH, Praetorius HA, Leipziger J (2007) Flow-induced $\left[\mathrm{Ca}^{2+}\right]_{\mathrm{i}}$ increase depends on nucleotide release and subsequent purinergic signaling in the intact nephron. J Am Soc Nephrol 18:2062-2070

Jensik PJ, Holbird D, Collard MW, Cox TC (2001) Cloning and characterization of a functional $\mathrm{P} 2 \mathrm{X}$ receptor from larval bullfrog skin. Am J Physiol Cell Physiol 281:C954-C962

Jiang L-H, Mackenzie AB, North RA, Surprenant A (2000) Brilliant blue G selectively blocks ATP-gated rat P2X7 receptors. Mol Pharmacol 58:82-88

Jiang L-H, Kim M, Spelta V, Bo X, Surprenant A, North RA (2003) Subunit arrangement in P2X receptors. J Neurosci 23:8903-8910

Juranka PF, Haghighi AP, Gaertner T, Cooper E, Morris CE (2001) Molecular cloning and functional expression of Xenopus laevis oocyte ATP-activated P2X4 channels. Biochim Biophys Acta 1512:111-124

Knight GE, Burnstock G (1996) The effects of purine compounds on the isolated aorta of the frog Rana temporaria. Br J Pharmacol 117:873-878

Laycock S, Taylor HC, Haigh C, Lee AT, Cooper GJ, Ong ACM, Robson L (2009) A novel dephosphorylation-activated conductance in a mouse renal collecting duct cell line. Exp Physiol 94:914-927

Le K-T, Babinski K, Seguela P (1998) Central P2X4 and P2X6 channel subunits coassemble into a novel heteromeric ATP receptor. J Neurosci 18:7152-7159

Le K-T, Boue-Grabot E, Archambault V, Seguela P (1999) Functional and biochemical evidence for heteromeric ATP-gated channels composed of P2X1 and P2X5 subunits. J Biol Chem 274:15415-15419

Lee YJ, Han HJ (2006) Role of ATP in DNA synthesis of renal proximal tubule cells: involvement of calcium, MAPKs, and CDKs. Am J Physiol Renal Physiol 291:F98-F106

Lee YJ, Park SH, Han HJ (2005) ATP stimulates $\mathrm{Na}^{+}$-glucose cotransporter activity via cAMP and p38 MAPK in renal proximal tubule cells. Am J Physiol Cell Physiol 289:C1268-C1276

Leipziger J, Unwin RJ (2003) Purinergic receptors in the kidney. In: Schwiebert EM (ed) Purinergic receptors and signalling. Academic Press, San Diego, pp 369-394

Lewis C, Neidhart S, Holy C, North RA, Buell G, Surprenant A (1995) Coexpression of P2X2 and P2X3 receptor subunits can account for ATP-gated currents in sensory neurons. Nature 377:432-435

Liu M, King BF, Dunn PM, Rong W, Townsend-Nicholson A, Burnstock G (2001) Coexpression of P2X3 and P2X2 receptor subunits in varying amounts generates heterogeneous populations of $\mathrm{P} 2 \mathrm{X}$ receptors that evoke a spectrum of agonist responses comparable to that seen in sensory neurons. J Pharmacol Exp Ther 296:1043-1050

Liu R, Bell PD, Peti-Peterdi J, Kovacs G, Johansson A, Persson AEG (2002) Purinergic receptor signaling at the basolateral membrane of macula densa cells. J Am Soc Nephrol 13:1145-1151

Lu M, MacGregor GG, Wang W, Giebisch G (2000) Extracellular ATP inhibits the small-conductance $\mathrm{K}$ channel on the apical membrane of the cortical collecting duct from mouse kidney. J Gen Physiol 116:299-310

Ma W, Korngreen A, Weil S, Cohen EB-T, Priel A, Kuzin L, Silberberg SD (2006) Pore properties and pharmacological features of the P2X receptor channel in airway ciliated cells. J Physiol 571:503-517

McCoy DE, Taylor AL, Kudlow BA, Karlson K, Slattery MJ, Schwiebert LM, Schwiebert EM, Stanton BA (1999) Nucleotides regulate $\mathrm{NaCl}$ transport in mIMCD-K2 cells via $\mathrm{P} 2 \mathrm{X}$ and $\mathrm{P} 2 \mathrm{Y}$ purinergic receptors. Am J Physiol Renal Physiol 277:F552F559

Mori M, Heuss C, Gahwiler BH, Gerber U (2001) Fast synaptic transmission mediated by $\mathrm{P} 2 \mathrm{X}$ receptors in $\mathrm{CA} 3$ pyramidal cells of rat hippocampal slice cultures. J Physiol 535:115-123

Mounfield PR, Robson L (1998) The role of $\mathrm{Ca}^{2+}$ in volume regulation induced by $\mathrm{Na}^{+}$-coupled alanine uptake in single proximal tubule cells isolated from frog kidney. J Physiol 510:145-153

Nicke A, Kerschensteiner D, Soto F (2005) Biochemical and functional evidence for heteromeric assembly of P2X1 and P2X4 subunits. J Neurochem 92:925-933

North RA, Barnard EA (1997) Nucleotide receptors. Curr Opin Neurobiol 7:346-357

Pochynyuk O, Bugaj V, Rieg T, Insel PA, Mironova E, Vallon V, Stockand JD (2008) Paracrine regulation of the epithelial $\mathrm{Na}^{+}$ channel in the mammalian collecting duct by purinergic P2Y2 receptor tone. J Biol Chem 283:36599-36607

Priel A, Silberberg SD (2004) Mechanism of ivermectin facilitation of human P2X4 receptor channels. J Gen Physiol 123:281-293

Radford KM, Virginio C, Surprenant A, North RA, Kawashima E (1997) Baculovirus expression provides direct evidence for heteromeric assembly of $\mathrm{P} 2 \mathrm{X} 2$ and $\mathrm{P} 2 \mathrm{X} 3$ receptors. J Neurosci 17:6529-6533

Rassendren F, Buell GN, Virginio C, Collo G, North RA, Surprenant A (1997) The permeabilizing ATP receptor, P2X7. Cloning and expression of a human cDNA. J Biol Chem 272:5482-5486

Robson L, Hunter M (1994a) Role of cell volume and protein kinase $\mathrm{C}$ in regulation of a $\mathrm{Cl}^{-}$conductance in single proximal tubule cells of Rana temporaria. J Physiol 480:1-7

Robson L, Hunter M (1994b) Volume-activated, gadolinium-sensitive whole-cell currents in single proximal cells of frog kidney. Pflugers Arch 429:98-106

Robson L, Hunter M (1994c) Volume regulatory responses in frog isolated proximal cells. Pflugers Arch 428:60-68

Robson L, Hunter M (1997) Two $\mathrm{K}^{+}$-selective conductances in single proximal tubule cells isolated from frog kidney are regulated by ATP. J Physiol 500:605-616

Robson L, Hunter M (2005) Mechanisms underlying regulation of a barium-sensitive $\mathrm{K}^{+}$conductance by ATP in single proximal tubule cells isolated from frog kidney. J Membr Biol 204:39-47

Silva GB, Garvin JL (2009) Extracellular ATP inhibits transport in medullary thick ascending limbs: role of P2X receptors. Am J Physiol Renal Physiol 297:F1168-F1173 
Solini A, Santini E, Chimenti D, Chiozzi P, Pratesi F, Cuccato S, Falzoni S, Lupi R, Ferrannini E, Pugliese G, Virgilio FD (2007) Multiple P2X receptors are involved in the modulation of apoptosis in human mesangial cells: evidence for a role of P2X4. Am J Physiol Renal Physiol 292:F1537-F1547

Stoop R, Surprenant A, North RA (1997) Different sensitivities to $\mathrm{pH}$ of ATP-induced currents at four cloned P2X receptors. J Neurophysiol 78:1837-1840

Takeda M, Kobayashi M, Endou H (1998) Establishment of a mouse clonal early proximal tubule cell line and outer medullary collecting duct cells expressing P2 purinoceptors. Biochem Mol Biol Int 44:657-664

Torres GE, Haines WR, Egan TM, Voigt MM (1998) Co-expression of P2X1 and P2X5 receptor subunits reveals a novel ATP-gated ion channel. Mol Pharmacol 54:989-993

Torres GE, Egan TM, Voigt MM (1999) Hetero-oligomeric assembly of P2X receptor subunits. Specificities exist with regard to possible partners. J Biol Chem 274:6653-6659

Valera S, Hussy N, Evans RJ, Adami N, North RA, Surprenant A, Buell G (1994) A new class of ligand-gated ion channel defined by P2x receptor for extracellular ATP. Nature 371:516-519

Vekaria RM, Unwin RJ, Shirley DG (2006) Intraluminal ATP concentrations in rat renal tubules. J Am Soc Nephrol 17:1841-1847

Virginio C, North RA, Surprenant A (1998a) Calcium permeability and block at homomeric and heteromeric $\mathrm{P} 2 \mathrm{X} 2$ and $\mathrm{P} 2 \mathrm{X} 3$ receptors, and $\mathrm{P} 2 \mathrm{X}$ receptors in rat nodose neurons. J Physiol 510:27-35

Virginio C, Robertson G, Surprenant A, North RA (1998b) Trinitrophenyl-substituted nucleotides are potent antagonists selective for $\mathrm{P} 2 \mathrm{X} 1, \mathrm{P} 2 \mathrm{X} 3$, and heteromeric $\mathrm{P} 2 \mathrm{X} 2 / 3$ receptors. Mol Pharmacol 53:969-973
Wang CZ, Namba N, Gonoi T, Inagaki N, Seino S (1996) Cloning and pharmacological characterization of a fourth $\mathrm{P} 2 \mathrm{X}$ receptor subtype widely expressed in brain and peripheral tissues including various endocrine tissues. Biochem Biophys Res Commun 220:196-202

Weidema AF, Barbera J, Dixon SJ, Sims SM (1997) Extracellular nucleotides activate non-selective cation and $\mathrm{Ca}^{2+}$-dependent $\mathrm{K}^{+}$channels in rat osteoclasts. J Physiol 503:303-315

Wildman SS, King BF, Burnstock G (1998) $\mathrm{Zn}^{2+}$ modulation of ATPresponses at recombinant $\mathrm{P} 2 \mathrm{X} 2$ receptors and its dependence on extracellular $\mathrm{pH}$. Br J Pharmacol 123:1214-1220

Wildman SSP, Marks J, Turner CM, Yew-Booth L, PeppiattWildman CM, King BF, Shirley DG, Wang W, Unwin RJ (2008) Sodium-dependent regulation of renal amiloride-sensitive currents by apical P2 receptors. J Am Soc Nephrol 19:731-742

Wildman SSP, Boone M, Peppiatt-Wildman CM, Contreras-Sanz A, King BF, Shirley DG, Deen PMT, Unwin RJ (2009) Nucleotides downregulate aquaporin 2 via activation of apical $\mathrm{P} 2$ receptors. J Am Soc Nephrol 20:1480-1490

Xia S-L, Wang L, Cash MN, Teng X, Schwalbe RA, Wingo CS (2004) Extracellular ATP-induced calcium signaling in mIMCD3 cells requires both $\mathrm{P} 2 \mathrm{X}$ and $\mathrm{P} 2 \mathrm{Y}$ purinoceptors. Am J Physiol Renal Physiol 287:F204-F214

Zhang Y, Sanchez D, Gorelik J, Klenerman D, Lab M, Edwards C, Korchev Y (2007) Basolateral P2X4-like receptors regulate the extracellular ATP-stimulated epithelial $\mathrm{Na}^{+}$channel activity in renal epithelia. Am J Physiol Renal Physiol 292:F1734-F1740

Zou H, Ugur M, Drummond RM, Singer JJ (2001) Coupling of a P2Zlike purinoceptor to a fatty acid-activated $\mathrm{K}^{+}$channel in toad gastric smooth muscle cells. J Physiol 534:59-70 